\title{
Declaração Universal dos Direitos Humanos Adotada E PROCLAMADA PELA RESOlUÇÃO 217 A (III) DA ASSEMBLÉIA GERAL DAS NaÇÕes Unidas EM 10 DE DEZEMBRo DE 1948
}

\section{PreÂmbulo}

Considerando que o reconhecimento da dignidade inerente a todos os membros da família humana e de seus direitos iguais e inalienáveis é o fundamento da liberdade, da justiça e da paz no mundo,

Considerando que o desprezo e o desrespeito pelos direitos humanos resultaram em atos bárbaros que ultrajaram a consciência da Humanidade e que o advento de um mundo em que os homens gozem de liberdade de palavra, de crença e da liberdade de viverem a salvo do temor e da necessidade foi proclamado como a mais alta aspiração do homem comum,

Considerando essencial que os direitos humanos sejam protegidos pelo Estado de Direito, para que o homem não seja compelido, como último recurso, à rebelião contra a tirania e a opressão,

Considerando essencial promover o desenvolvimento de relaçóes amistosas entre as nações,

Considerando que os povos das Nações Unidas reafirmaram, na Carta, sua fé nos direitos humanos fundamentais, na dignidade e no valor da pessoa humana e na igualdade de direitos dos homens e das mulheres, e que decidiram promover o progresso social e melhores condiçôes de vida em uma liberdade mais ampla,

Considerando que os Estados-Membros se comprometeram a desenvolver, em cooperação com as Nações Unidas, o respeito universal aos direitos humanos e liberdades fundamentais e a observância desses direitos e liberdades,

Considerando que uma compreensão comum desses direitos e liberdades é da mais alta importância para o pleno cumprimento desse compromisso, 


\section{A Assembléta Geral proclama}

A presente Declaração Universal dos Diretos Humanos como o ideal comum a ser atingido por todos os povos e todas as naçóes, com o objetivo de que cada indivíduo e cada órgão da sociedade, tendo sempre em mente esta Declaração, se esforce, através do ensino e da educação, por promover o respeito a esses direitos e liberdades, e, pela adoção de medidas progressivas de caráter nacional e internacional, por assegurar o seu reconhecimento e a sua observância universais e efetivos, tanto entre os povos dos próprios Estados-Membros, quanto entre os povos dos territórios sob sua jurisdição.

\section{ArTigo I}

Todas as pessoas nascem livres e iguais em dignidade e direitos. São dotadas de razão e consciência e devem agir em relação umas às outras com espírito de fraternidade.

\section{ArTigo II}

1. Toda pessoa tem capacidade para gozar os direitos e as liberdades estabelecidos nesta Declaração, sem distinção de qualquer espécie, seja de raça, cor, sexo, língua, religião, opinião política ou de outra natureza, origem nacional ou social, riqueza, nascimento, ou qualquer outra condição.

2. Não será também feita nenhuma distinção fundada na condição política, jurídica ou internacional do país ou território a que pertença uma pessoa, quer se trate de um território independente, sob tutela, sem governo próprio, quer sujeito a qualquer outra limitação de soberania.

\section{ArTigo III}

Toda pessoa tem direito à vida, à liberdade e à segurança pessoal.

\section{ArTigo IV}

Ninguém será mantido em escravidão ou servidão, a escravidão e o tráfico de escravos serão proibidos em todas as suas formas. 


\section{Artigo V}

Ninguém será submetido à tortura, nem a tratamento ou castigo cruel, desumano ou degradante.

\section{Artigo VI}

Toda pessoa tem o direito de ser, em todos os lugares, reconhecida como pessoa perante a lei.

\section{Artigo VII}

Todos são iguais perante a lei e têm direito, sem qualquer distinção, a igual proteção da lei. Todos têm direito a igual proteção contra qualquer discriminação que viole a presente Declaração e contra qualquer incitamento a tal discriminação.

\section{Artigo VIII}

Toda pessoa tem direito a receber dos tributos nacionais competentes remédio efetivo para os atos que violem os direitos fundamentais que lhe sejam reconhecidos pela constituição ou pela lei.

\section{Artigo IX}

Ninguém será arbitrariamente preso, detido ou exilado.

\section{Artigo X}

Toda pessoa tem direito, em plena igualdade, a uma audiência justa e pública por parte de um tribunal independente e imparcial, para decidir de seus direitos e deveres ou do fundamento de qualquer acusação criminal contra ele.

\section{Artigo XI}

1. Toda pessoa acusada de um ato delituoso tem o direito de ser presumida inocente até que a sua culpabilidade tenha sido provada de acordo com a lei, em julgamento público no qual the tenham sido asseguradas todas as garantias necessárias à sua defesa. 
2. Ninguém poderá ser culpado por qualquer ação ou omissão que, no momento, não constituíam delito perante o direito nacional ou internacional. Tampouco será imposta pena mais forte do que aquela que, no momento da prática, era aplicável ao ato delituoso.

\section{ArTigo XII}

Ninguém será sujeito a interferências na sua vida privada, na sua família, no seu lar ou na sua correspondência, nem a ataques à sua honra e reputação. Toda pessoa tem direito à proteção da lei contra tais interferências ou ataques.

\section{Artigo XIII}

1. Toda pessoa tem direito à liberdade de locomoção e residência dentro das fronteiras de cada Estado.

2. Toda pessoa tem o direito de deixar qualquer país, inclusive o próprio, e a este regressar.

\section{ArTigo XIV}

1. Toda pessoa, vítima de perseguição, tem o direito de procurar e de gozar asilo em outros países.

2. Este direito não pode ser invocado em caso de perseguição legitimamente motivada por crimes de direito comum ou por atos contrários aos propósitos e princípios das Nações Unidas.

\section{ArTigo XV}

1. Toda pessoa tem direito a uma nacionalidade.

2. Ninguém será arbitrariamente privado de sua nacionalidade, nem do direito de mudar de nacionalidade.

\section{Artigo XVI}

1. Os homens e mulheres de maior idade, sem qualquer restrição de raça, nacionalidade ou religião, têm o direito de contrair matrimônio e fundar uma família. Gozam de iguais direitos em relação ao casamento, sua duração e sua dissolução.

2. O casamento não será válido senão com o livre e pleno consentimento dos nubentes. 
3. A família é o núcleo natural e fundamental da sociedade e tem direito à proteção da sociedade e do Estado.

\section{ArTigo XVII}

1. Toda pessoa tem direito à propriedade, só ou em sociedade com outros.

2. Ninguém será arbitrariamente privado de sua propriedade.

\section{ARTIGo XVIII}

Toda pessoa tem direito à liberdade de pensamento, consciência e religião; este direito inclui a liberdade de mudar de religião ou crença e a liberdade de manifestar essa religião ou crença, pelo ensino, pela prática, pelo culto e pela observância, isolada ou coletivamente, em público ou em particular.

\section{Artigo XIX}

Toda pessoa tem direito à liberdade de opinião e expressão; este direito inclui a liberdade de, sem interferência, ter opiniōes e de procurar, receber e transmitir informações e idéias por quaisquer meios e independentemente de fronteiras.

\section{Artigo XX}

1. Toda pessoa tem direito à liberdade de reunião e associação pacíficas.

2. Ninguém pode ser obrigado a fazer parte de uma associação.

\section{Artigo XXI}

1. Toda pessoa tem o direito de tomar parte no governo de seu país, diretamente ou por intermédio de representantes livremente escolhidos.

2. Toda pessoa tem igual direito de acesso ao serviço público do seu país.

3. A vontade do povo será a base da autoridade do governo; esta vontade será expressa em eleições periódicas e legítimas, por sufrágio universal, por voto secreto ou processo equivalente que assegure a liberdade de voto.

\section{ArTigo XXII}

Toda pessoa, como membro da sociedade, tem direito à segurança social e à realização, pelo esforço nacional, pela cooperação internacional e de acordo com a organização e recursos de cada Estado, dos direitos econômicos, sociais e culturais indispensáveis à sua dignidade e ao livre desenvolvimento da sua personalidade. 


\section{Artigo XXIII}

1. Toda pessoa tem direito ao trabalho, à livre escolha de emprego, a condições justas e favoráveis de trabalho e à proteção contra o desemprego.

2. Toda pessoa, sem qualquer distinção, tem direito a igual remuneração por igual trabalho.

3. Toda pessoa que trabalhe tem direito a uma remuneração justa e satisfatória, que lhe assegure, assim como à sua família, uma existência compatível com a dignidade humana, e a que se acrescentarão, se necessário, outros meios de proteção social.

4. Toda pessoa tem direito a organizar sindicatos e neles ingressar para proteção de seus interesses.

\section{ARTIGo XXIV}

Toda pessoa tem direito a repouso e lazer, inclusive a limitação razoável das horas de trabalho e férias periódicas remuneradas.

\section{ArTigo XXV}

1. Toda pessoa tem direito a um padrão de vida capaz de assegurar a si e a sua família saúde e bem-estar, inclusive alimentação, vestuário, habitação, cuidados médicos e os serviços sociais indispensáveis, e direito à segurança em caso de desemprego, doença, invalidez, viuvez, velhice ou outros casos de perda dos meios de subsistência fora de seu controle.

2. A maternidade e a infância têm direito a cuidados e assistência especiais. Todas as crianças nascidas dentro ou fora do matrimônio gozarão da mesma proteção social.

\section{ArTigo XXVI}

1. Toda pessoa tem direito à instrução. A instrução será gratuita, pelo menos nos graus elementares e fundamentais. A instrução elementar será obrigatória. A instrução técnico-profissional será acessível a todos, bem como a instrução superior, esta baseada no mérito.

2. A instrução será orientada no sentido do pleno desenvolvimento da personalidade humana e do fortalecimento do respeito pelos direitos humanos e pelas liberdades fundamentais. A instrução promoverá a compreensão, a tolerância e a amizade entre todas as naçóes e grupos raciais ou religiosos e coadjuvará as atividades das Nações Unidas em prol da manutenção da paz. 
3. Os pais têm prioridade de direito na escolha do gênero de instrução que será ministrada a seus filhos.

\section{Artigo XXVII}

1. Toda pessoa tem o direito de participar livremente da vida cultural da comunidade, de fruir as artes e de participar do processo científico e de seus benefícios.

2. Toda pessoa tem direito à proteção dos interesses morais e materiais decorrentes de qualquer produção científica, literária ou artística da qual seja autor.

\section{ArTigo XXVIII}

Toda pessoa tem direito a uma ordem social e internacional em que os direitos e liberdades estabelecidos na presente Declaração possam ser plenamente realizados.

\section{Artigo XXIX}

1. Toda pessoa tem deveres para com a comunidade, em que o livre e pleno desenvolvimento de sua personalidade é possível.

2. No exercício de seus direitos e liberdades, toda pessoa estará sujeita apenas às limitações determinadas pela lei, exclusivamente com o fim de assegurar o devido reconhecimento e respeito dos direitos e liberdades de outrem e de satisfazer às justas exigências da moral, da ordem pública e do bem-estar de uma sociedade democrática.

3. Esses direitos e liberdades não podem, em hipótese alguma, ser exercidos contrariamente aos propósitos e princípios das Nações Unidas.

\section{ArTigo XXX}

Nenhuma disposição da presente Declaração pode ser interpretada como o reconhecimento a qualquer Estado, grupo ou pessoa, do direito de exercer qualquer atividade ou praticar qualquer ato destinado à destruição de quaisquer dos direitos e liberdades aqui estabelecidos. 